\title{
Irradiation of ready meals for microbiological safety and shelf-life extension. 1. Microbiological quality of waakye and other ready-to-eat meals
}

\author{
J. NKETSIA-TABIRI, A. ADU-GYAMFI \&A. OWUSU-BINEY \\ Department of Food Science and Radiation Processing, Biotechnology and Nuclear Agriculture \\ Research Institute, Ghana Atomic Energy Commission, P. O. Box LG 80, Legon, Ghana
}

\begin{abstract}
Waakye bought from the open market and 14 meals prepared under the hazard analysis and critical control point (HACCP) plan were microbiologically investigated. The aerobic mesophilic count (AMC) $\left(10^{7}-10^{8} \mathrm{CFU} \mathrm{g} \mathrm{g}^{-1}\right)$ and coliform count $\left(10^{6}-10^{7} \mathrm{CFU} \mathrm{g}^{-1}\right)$ for complete waakye meals, including macaroni, fried fish, sauce and vegetable salad, exceeded the microbiological standards for such ready-to-eat meals. The AMC $\left(10^{1}-10^{4} \mathrm{CFU} \mathrm{g}^{-1}\right)$ and coliform count $\left(10^{1}-10^{2} \mathrm{CFU} \mathrm{\textrm {g } ^ { - 1 }}\right)$ for all the ready meals prepared under HACCP and stored $\left(-5\right.$ to $\left.0{ }^{\circ} \mathrm{C}\right)$ for up to 5 days were within the standards. Potential pathogens isolated from waakye and the meals prepared under HACCP plan included Escherichia coli, Klebsiella spp., Serratia spp., and Enterobacter spp. Subsequent studies will exploit the potential of irradiation to eliminate pathogens and ensure the microbiological safety of ready-to-eat meals.
\end{abstract}

Original scientific paper. Received 18 Sep 03; revised 30 Jul 04.

\section{RÉSUMÉ}

Nketsia-Tabiri, J., Adu-Gyamfi, A. \& Owusu-Biney, A. Irradiation $d u$ plat cuisiné pour la sécurité microbiologique et la prolongation de la durée de conservation en stock: La qualité microbiologique de waakye et d'autres repas cuisinés. Waakye (riz et haricot cuisinés ensemble) acheté de la vente libre ainsi que quatorze repas préparés sous le critique (ARPCC) étaient enquetés par la méthode microbiologique. Le compte

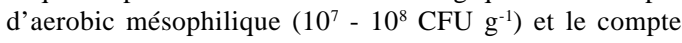
coliforme $\left(10^{6}-10^{7} \mathrm{CFU} \mathrm{\textrm {g } ^ { - 1 }}\right)$ pour le repas de Waakye complet qui comprenait le macaroni, le poisson frit, la sauce et la salade de légumes dépassaient les normes microbiologiqes pour tels repas cuisinés. Le compte d'aerobic mésophilique $\left(10^{1}-10^{4} \mathrm{CFU} \mathrm{g}^{-1}\right)$ et le compte coliforme $\left(10^{1}-10^{2} \mathrm{CFU} \mathrm{\textrm {g } ^ { - 1 }}\right)$ pour tous les plats cuisinés préparés sous ARPCC et conservés au froid $\left(-5\right.$ à $\left.0{ }^{\circ} \mathrm{C}\right)$ pour 5 jours étaient aux niveaux requis. Les agents pathogènes potentiels isolés de waakye et des repas préparés sous le plan d'ARPCC comprenaient Escherichia coli, Klebsiella spp., Serratia spp., and Enterobacter spp. Les études à venir vont exploiter l'utilisation d'irradiation pour éliminer les agents pathogènes et assurer la sécurité microbiologique des repas cuisinés.

\section{Introduction}

Current trends in particularly developed countries suggest increasing demand for convenient foods such as ready meals and those that require minimum preparation before consumption. In Ghana, the trend is the same, with "street foods" (readyto-eat meals sold in the informal sector) playing a major role in meeting the nutritional needs of the people (GLSS, 1988/89, 1998/99). In most developing countries including Ghana, these ready meals are prepared daily. With increasing urban- ization and increased use of refrigerators for food preservation in developing countries, "street foods" could soon be sold in supermarkets.

The hygienic limitations of "street foods" in Ghana and elsewhere have been recognized and reported (Mosupuye \& von Holy, 1999; Bryan et al., 1997; FAO/GHANA, 1997; Nkansah, 1996; Swanepoel et al., 1995). Ready-to-eat smoked mackerel served in "chop bars" and chicken pieces from food service outlets in Accra have been reported to harbour varying levels of indicator or- 
ganisms, sometimes as high as $10^{9} \mathrm{CFU} \mathrm{g}^{-1}$ (AduGyamfi, 2000; Hayford, 1979). Organisms of public health concern isolated from these foods included faecal Streptococci, coagulase-positive Staphylococcus aureus and faecal coliforms, notably Escherichia coli and Shigella flexneri. Studies on waakye (co-boiled rice and cowpea), a ready-to-eat meal, indicated that the cooking step applied is adequate for inactivating vegetative bacteria, but not spores (FAO/GHANA, 1997). Consequently, Staphylococcus aureus and Clostridium perfringens have been isolated from waakye and gravy during 2 to $7 \mathrm{~h}$ holding under ambient conditions, although counts did not exceed $10^{3} \mathrm{CFU} \mathrm{g}^{-1}$ (FAO/GHANA, 1997). The implication of the heat stability, survival of spores of the indicator bacteria, and their subsequent germination and proliferation during holding of waakye is a serious public health concern. Because waakye may not be consumed immediately after purchase, but may be held under ambient conditions for many more hours. Other researchers have also reported proliferation of microbes on ready-to-eat meals during holding (Bryan et al., 1997).

Before consumption, waakye may be reheated. The fact that reheating reduces microbial counts on waakye to < $10 \mathrm{CFU} \mathrm{g}^{-1}$ (FAO/GHANA, 1997) might not necessarily render the food safe, especially if heat-stable toxins have already been produced by pathogens. It is imperative that meals are prepared by hygienic and preventative procedures, coupled with effective treatments for eliminating vegetative cells and spores for safety assurance. The preparation of meals by the HACCP approach improves their microbiological quality. The HACCP, a systematic approach to hazard identification, assessment and control, also involves identifying critical control points of hazards and establishing procedures to monitor these points (ICMSF, 1989). However, HACCP might not ensure the safety of meals if the consumer does not strictly follow the recommended post-processing handling instructions. Irradiation is widely recognized as an effective control measure for inacti- vating pathogenic bacteria and parasites from food, especially those eaten raw or minimally processed (IAEA, 2003).

This study investigated the microbiological quality of waakye and other ready-to-eat meals prepared under HACCP from selected sources, aiming at considering irradiation as a potential treatment for ensuring their microbiological safety.

\section{Materials and methods}

Samples of waakye (co-boiled rice and beans) complete with their accompaniments (sauce/gravy/ pepper, fried fish, macaroni, gari and uncooked salads (lettuce, tomato, onion, cabbage) were bought from street vendors from three suburbs (Dome, Madina and Haatso) of Accra in Ghana.

Meals, prepared under HACCP plan, were also bought from two caterers. Altogether, 14 meals were randomly selected by the chefs after preparation and held under the normal storage conditions for hot meals $\left(-5\right.$ to $\left.0{ }^{\circ} \mathrm{C}\right)$ until they were collected and transported on ice to the laboratory for analysis.

Twenty-gram portions of the samples were homogenised in a stomacher (Mix 2, AES Laboratoire, France) for $1 \mathrm{~min}$. Ten grams of each sample was added to $90-\mathrm{ml}$ peptone water $(1 \%$ peptone water $+0.5 \% \mathrm{NaC} 1)$ and placed on a mechanical shaker (Junior Orbit Shaker, Lab-Line Instruments, USA) for $30 \mathrm{~min}$. Standard methods (APHA, 1976) were used in determining the microbiological indices of AMC (Plate Count Agar; Oxoid, UK; incubated at $36{ }^{\circ} \mathrm{C} / 48 \mathrm{~h}$ ); general coliform count (Eosin Methylene Blue Agar; Difco, USA; incubated at $36{ }^{\circ} \mathrm{C} / 48 \mathrm{~h}$ ); Salmonella/Shigella count (S/S Agar with Selenite Broth enrichment; Difco, USA; incubated at $36{ }^{\circ} \mathrm{C} / 24-48 \mathrm{~h}$ ); mould and yeast count (Oxytetracycline $(0.01 \%)$ Glucose Yeast Agar; Merck, Germany; incubated at $\left.28^{\circ} \mathrm{C} / 72 \mathrm{~h}\right)$.

Representative colonies from the plate counts were purified by sub-culturing and identified using morphological characteristics and standard biochemical tests. The tests used were Gram stain, catalase, oxidase, motility, nitrate, carbohydrate fer- 
mentations, triple sugar iron, and the IMViC tests with reference to Biochemical Tests for Identification of Medical Bacteria (Mac Faddin, 1980).

\section{Results}

Waakye and its accompaniments

The AMC for complete waakye meals ranged between $8.1 \times 10^{7}$ and $1.3 \times 10^{8} \mathrm{CFU} \mathrm{g}^{-1}$ (Table 1), whilst coliform count ranged between 5.8 and 9.7 $\times 10^{6} \mathrm{CFU} \mathrm{g}^{-1}$. These values are comparable to the counts recorded for macaroni $\left(9.6 \times 10^{7}-9.9 \times 10^{8}\right.$ CFU g $\left.{ }^{-1}\right)$ and salad $\left(5.7 \times 10^{7}-5.4 \times 10^{8} \mathrm{CFU} \mathrm{g}^{-1}\right)$. Lower AMC $\left(3.9 \times 10^{4}-1.8 \times 10^{5} \mathrm{CFU} \mathrm{g}^{-1}\right)$ and coliform count $\left(7.0 \times 10-3.3 \times 10^{2} \mathrm{CFU} \mathrm{g}^{-1}\right)$ were recorded for waakye only. The fried fish also had high coliform count $\left(3.5 \times 10^{4}-6.3 \times 10^{6} \mathrm{CFU} \mathrm{g}^{-1}\right)$. Mould and yeast counts were highest on the raw vegetable salad, but could not be detected on waakye alone. Although Salmonella and Shigella could not be detected on any of the samples, the results have serious implications because the counts exceeded the microbiological standards for such short shelf-life foods $\left(<10^{5} \mathrm{CFU} \mathrm{g}^{-1}\right.$ at $36^{\circ} \mathrm{C} /$ $48 \mathrm{~h} \mathrm{AMC} ;<10^{4} \mathrm{CFU} \mathrm{g}^{-1}$ at $36^{\circ} \mathrm{C} / 48 \mathrm{~h}$ coliforms).

Identification of isolates from positive coliform plates showed that Klebsiella spp., Enterobacter spp., and Citrobacter freundii were present on the complete waakye meals.

\section{Meals prepared under HACCP plan}

The meals were held between -5 and $0{ }^{\circ} \mathrm{C}$ for periods ranging from 0 to 5 days (Table 2). The AMC ranged between $1.5 \times 10^{2}$ and $9.4 \times 10^{4} \mathrm{CFU}$ $\mathrm{g}^{-1}$, whilst coliform count ranged between $1.0 \times 10^{1}$ and $1.4 \times 10^{3} \mathrm{CFU} \mathrm{g}^{-1}$. One of the meals coded HAP-3 had no coliform colonies after $48 \mathrm{~h}$ incubation. The presence of Salmonella and Shigella could not be established on any of the meals, because no growth of microbes was observed on the selective SS agar.

Identification of isolates from the meals indicated that potential pathogens including Klebsiella spp., Enterobacter spp., Serratia spp., and Escherichia coli were present (Table 2).
TABLE 1

Microbiological Counts on Waakye and Its Accompaniments

\begin{tabular}{lccc}
\hline Sample & Aerobic mesophilic & Coliform & Mould and yeast \\
\hline Complete $^{\mathrm{a}}$ & $8.1 \times 10^{7 \mathrm{~b}}$ & $5.8 \times 10^{6}$ & $3.5 \times 10^{3}$ \\
Waakye & $1.3 \times 10^{8}$ & $9.7 \times 10^{6}$ & $4.2 \times 10^{5}$ \\
Waakye only & $3.9 \times 10^{4}$ & $7.0 \times 10$ & $\mathrm{ND}$ \\
& $1.8 \times 10^{5}$ & $3.3 \times 10^{2}$ & $\mathrm{ND}$ \\
Fried fish & $8.3 \times 10^{4}$ & $3.5 \times 10^{4}$ & $1.5 \times 10$ \\
& $1.2 \times 10^{7}$ & $6.3 \times 10^{6}$ & $8.3 \times 10^{4}$ \\
Hydrated gari & $2.7 \times 10^{2}$ & $1.0 \times 10$ & $\mathrm{ND}$ \\
& $1.8 \times 10^{4}$ & $3.4 \times 10^{3}$ & $9.0 \times 10$ \\
Cooked & $9.6 \times 10^{7}$ & $9.5 \times 10^{6}$ & $4.5 \times 10$ \\
macaroni & $9.9 \times 10^{8}$ & $9.5 \times 10^{7}$ & $3.8 \times 10^{2}$ \\
& $5.7 \times 10^{7}$ & $8.5 \times 10^{6}$ & $5.5 \times 10^{3}$ \\
Vegetable & $5.4 \times 10^{8}$ & $6.5 \times 10^{7}$ & $6.0 \times 10^{4}$ \\
salad & &
\end{tabular}

${ }^{a}$ Waakye, sauce, fried fish, hydrated gari, macaroni and salad. ND - not detected

${ }^{\mathrm{b}}$ Range (minimum and maximum counts)

\section{Discussion} The AMC $\left(10^{4}-10^{5} \mathrm{CFU} \mathrm{g}^{-1}\right)$ on waakye (Table 1) agreed with those reported (FAO/ GHANA, 1997). However, because waakye is eaten with all its accompaniments, the high TVC $\left(10^{7}-10^{8} \mathrm{CFU}\right.$ $\left.\mathrm{g}^{-1}\right)$ and coliform count $\left(10^{5}\right.$ $10^{7} \mathrm{CFU} \mathrm{g}^{-1}$ ) for the complete waakye (Table 1) show the microbiological quality of waakye better. High coliform counts $\left(10^{6}-10^{8}\right.$ org g $\left.^{-1}\right)$ have also been reported for readyto-eat chicken pieces after $8 \mathrm{~h}$ holding during marketing under ambient conditions (Hayford, 1979).

The observed high count on the vegetable salad and macaroni (Table 1) and the 
TABLE 2

Microbiological Quality of Meals Prepared Under HACCP Plan

\begin{tabular}{|c|c|c|c|c|}
\hline $\begin{array}{l}\text { Meal } \\
\text { code }\end{array}$ & $\begin{array}{l}\text { Days holding } \\
\left(-5 \text { to } 0^{\circ} \mathrm{C}\right)\end{array}$ & $\begin{array}{c}A M C^{a} \\
\left(C F U g^{-1}\right)\end{array}$ & $\begin{array}{l}\text { Coliform } \\
\left(C F U g^{-1}\right)\end{array}$ & Isolate \\
\hline $\mathrm{HAP}-1^{\mathrm{c}}$ & 2 & $\begin{array}{l}8.5 \times 10^{4 \mathrm{~b}} \\
9.4 \times 10^{4}\end{array}$ & $\begin{array}{l}7.8 \times 10^{2} \\
8.8 \times 10^{2}\end{array}$ & $\begin{array}{l}\text { Pseudomonas spp. } \\
\text { Alkaligenes spp. }\end{array}$ \\
\hline HAP-2 & 3 & $\begin{array}{l}6.4 \times 10^{4} \\
7.3 \times 10^{4}\end{array}$ & $\begin{array}{l}2.0 \times 10 \\
3.0 \times 10\end{array}$ & E. coli, Enterobacter spp. \\
\hline HAP-3 & 4 & $\begin{array}{l}2.0 \times 10^{2} \\
2.3 \times 10^{2}\end{array}$ & $\begin{array}{l}\text { ND } \\
\text { ND }\end{array}$ & No coliform isolates \\
\hline HAP-4 & 2 & $\begin{array}{l}4.9 \times 10^{2} \\
5.2 \times 10^{2}\end{array}$ & $\begin{array}{l}1.0 \times 10 \\
2.0 \times 10\end{array}$ & Acinetobacter spp. \\
\hline HAP-5 & 3 & $\begin{array}{l}1.1 \times 10^{4} \\
1.2 \times 10^{4}\end{array}$ & $\begin{array}{l}3.0 \times 10^{3} \\
8.5 \times 10^{3}\end{array}$ & $\begin{array}{l}\text { Acinetobacter spp. } \\
\text { Serratia spp. }\end{array}$ \\
\hline HAP-6 & 4 & $\begin{array}{l}3.2 \times 10^{2} \\
3.7 \times 10^{2}\end{array}$ & $\begin{array}{l}1.8 \times 10^{2} \\
2.6 \times 10^{2}\end{array}$ & Acinetobacter spp. \\
\hline НАР-7 & 4 & $\begin{array}{l}7.6 \times 10^{4} \\
8.5 \times 10^{4}\end{array}$ & $\begin{array}{l}4.7 \times 10^{2} \\
7.8 \times 10^{2}\end{array}$ & Enterobacter spp. \\
\hline НАР-8 & 4 & $\begin{array}{l}4.9 \times 10^{3} \\
5.4 \times 10^{3}\end{array}$ & $\begin{array}{l}4.0 \times 10^{2} \\
4.5 \times 10^{2}\end{array}$ & $\begin{array}{l}\text { Serratia spp. } \\
\text { Enterobacter spp. }\end{array}$ \\
\hline HAP-9 & 5 & $\begin{array}{l}5.6 \times 10^{3} \\
5.9 \times 10^{3}\end{array}$ & $\begin{array}{l}1.2 \times 10^{3} \\
1.4 \times 10^{3}\end{array}$ & $\begin{array}{l}\text { E. coli, Klebsiella spp. } \\
\text { Acinetobacter spp. }\end{array}$ \\
\hline HAP-10 & 0 & $\begin{array}{l}5.3 \times 10^{3} \\
5.4 \times 10^{3}\end{array}$ & $\begin{array}{l}4.0 \times 10 \\
6.0 \times 10\end{array}$ & $\begin{array}{l}\text { Acinetobacter spp. } \\
\text { Serratia spp. }\end{array}$ \\
\hline HAP-11 & 2 & $\begin{array}{c}9.8 \times 10^{2} \\
10.0 \times 10^{2}\end{array}$ & $\begin{array}{l}2.5 \times 10^{2} \\
2.7 \times 10^{2}\end{array}$ & $\begin{array}{l}\text { Acinetobacter spp. } \\
\text { Serratia spp. }\end{array}$ \\
\hline HAP-12 & 2 & $\begin{array}{l}1.5 \times 10^{2} \\
2.1 \times 10^{2}\end{array}$ & $\begin{array}{l}2.0 \times 10 \\
3.0 \times 10\end{array}$ & Acinetobacter spp. \\
\hline HAP-13 & 4 & $\begin{array}{l}1.4 \times 10^{4} \\
5.7 \times 10^{4}\end{array}$ & $\begin{array}{l}4.0 \times 10 \\
6.0 \times 10\end{array}$ & $\begin{array}{l}\text { Enterobacter spp. } \\
\text { Klebsiella spp. }\end{array}$ \\
\hline HAP-14 & 2 & $\begin{array}{l}1.1 \times 10^{3} \\
1.2 \times 10^{3}\end{array}$ & $\begin{array}{c}\text { ND } \\
4.0 \times 10\end{array}$ & $\begin{array}{l}\text { Enterobacter spp. } \\
\text { Acinetobacter spp. }\end{array}$ \\
\hline
\end{tabular}

${ }^{\mathrm{a}}$ AMC - Aerobic mesophilic count ${ }^{\mathrm{b}}$ Actual counts for replicate tests $\quad$ ND - not detected

${ }^{c}$ Meal ingredients-

HAP-1: Fish fillet, cheese, sauce, oil, potato, spices, vegetables HAP-8: Chicken, peppers, curry, oil, steamed rice

HAP-2: Deboned chicken, spices, oil, plain rice, potato

HAP-3: Chicken, spices, sauce, oil, steamed rice, potato

AAP-9: Fish, spices, oil, potato, sauce

HAP-4: Beef steak, spices, oil, potato, tomato, peppers

HAP-10: Eggs, salt, oil

HAP-11: Eggs, salt, oil

HAP-5: Beef steak, spices, sauce, oil, steamed rice

HAP-12: Lamb, spices, oil

HAP-6: Chicken breast, spices, oil, boiled rice, sauce

HAP-13: Chicken, spices, oil, vegetables, rice

HAP-7: Fish fillet, spices, oil, sauce, potato

HAP-14: Biscuit, fruits, cheese, cream 
fact that they reflected the high count for complete waakye deserve further investigation. Uncooked vegetable salads have high microbial load unless strict procedures, including thorough washing and sanitization, are followed to reduce microbial load while subsequent refrigeration or chilling is required to control microbial growth (Farkas et al., 1997; Beuchat, 1996). Discussions with and observation of waakye processors showed that the vegetable salads were washed with potable water, comminuted and displayed together with other accompaniments of waakye, during marketing. No effective sanitizing treatment is applied to the salads. Earlier studies (FAO/GHANA, 1997) also indicated that accompaniments of waakye such as salads and pepper sauce, which are minimally processed, had higher counts (AMC $>4 \times$ $10^{3} \mathrm{CFU} \mathrm{g}^{-1}$; Staphylococcus aureus $>3 \times 10^{4} \mathrm{CFU}$ $\mathrm{g}^{-1}$, and Bacillus cereus $>2 \times 10^{5} \mathrm{CFU} \mathrm{g}^{-1}$ ).

Direct observation of waakye sellers also suggested cross-contamination resulting from the use of fingers or the same ladle to serve the salads, cooked macaroni and waakye. Although the use of different ladles would largely prevent crosscontamination of the bulk of the meal composites, this would not prevent the complete waakye meal from being contaminated as the results of this study indicate (Table 1). The only measure for the safety of any complete meal is to ensure that each accompaniment, especially the minimally processed such as uncooked salads, are microbiologically safe. Isolates from the positive coliform plates of complete waakye included Citrobacter freundii, Klebsiella spp., and Enterobacter spp.; these have public health implications (Anon, 1996; Klipstein, Engert \& Short 1977).

The poor microbiological quality of many street foods might result from the combined effect of using ineffective sanitary procedures to prepare uncooked or minimally processed foods, post-processing contamination, and long holding under conditions which enhance proliferation of microorganisms. Improving sanitary conditions under which 'street foods' are prepared and marketed and assisting stakeholders to adopt effective pre- ventive procedures, based on the HACCP approach, to convert the raw food ingredients into ready-to-eat meals are important in ensuring food safety and good public health.

The microbiological quality of 14 ready-to-eat meals prepared under HACCP plan indicated that for all the meals, the counts recorded (Table 2) did not exceed the microbiological standards of short shelf-life foods $\left(<10^{5} \mathrm{CFU} \mathrm{g}^{-1}\right.$ at $36^{\circ} \mathrm{C} / 48 \mathrm{~h} \mathrm{AMC}$ and $<10^{4} \mathrm{CFU} \mathrm{g}^{-1}$ at $36^{\circ} \mathrm{C} / 48 \mathrm{~h}$ coliforms). These results show the important contribution that the HACCP plan can make toward ensuring food safety when it is implemented effectively.

Table 2 further shows that holding the meals at 0 to $-5{ }^{\circ} \mathrm{C}$ controlled the proliferation of microbes. This is supported by the observation that HAP10 , which was analysed soon after production (i.e., 0 holding time), had higher AMC and coliforms than HAP-11, which is the same meal held (-5 to 0 ${ }^{\circ} \mathrm{C}$ ) for 2 days. Although all the meals are supplied to clients within $24 \mathrm{~h}$ of preparation, it is important to investigate the microbiological quality of some meals if they are held for over $24 \mathrm{~h}$. The counts for meals which were held for up to 5 days were also within the microbiological standards. Potential pathogens isolated from the meals prepared under the HACCP plan (Table 2 ) included enterotoxigenic bacteria such as E. coli, Serratia spp., and Klebsiella spp. (Anon, 1996; Klipstein et al., 1977). The last two species were also isolated from the complete waakye meals. The results suggested that implementing HACCP reduced microbial counts substantially; however, some potential pathogens survived.

Although the HACCP plan requires that the ready meals are held at -5 to $0{ }^{\circ} \mathrm{C}$ to suppress growth of survivors, they could proliferate if the meals are subjected to temperature abuse such as during power outages. It is necessary to adopt processes and technologies which can eliminate potential pathogens from prepared meals and improve their microbiological safety. Food irradiation is a proven technology for eliminating pathogens and ensuring food safety. 


\section{Conclusion}

The microbiological count on all samples of waakye bought from the open market exceeded the microbiological standards for such short shelflife foods. Although microbiological counts on meals prepared under HACCP agreed with the requisite microbiological standards, the potential pathogens identified on some meals is noteworthy. Potential pathogens need to be eliminated from waakye as well as ready meals prepared under HACCP to ensure their microbiological safety. Radiation processing is a proven technology for eliminating potential pathogens, but has no adverse effects on nutritional and sensory quality of meals. Subsequent studies will exploit the potential of irradiation to eliminate pathogens and ensure the microbiological safety of ready-to-eat meals.

\section{Acknowledgement}

The authors gratefully acknowledge the technical assistance of Messrs E. Akolmolga, T. Mahami and C. Owulah.

\section{REFERENCES}

Adu-Gyamfi, A. (2000) Studies on microbiological quality of ready-to-eat smoked fish. BNARI Technical Report.

Anon. (1996) Intestinally pathogenic Escherichia coli. In Microorganisms in foods, 1st ed. 5, 126-140. ICMSF. Blackie Academic \& Professional Press.

APHA (1976) Compendium of methods for the microbiological examination of foods (ed. M. K. Speck). Washington, DC: American Public Health Association.

Beuchat, L. R. (1996) Pathogenic microorganisms associated with fresh produce. J. Fd Prot. 59, 204216.

Bryan, F. L., Jermini, M., Schmitt, R., Chilufya, E. N., Mwansa, M., Matoba, A., Mfume, E. \&
Chibiya, H. (1997) Hazards associated with holding and reheating foods at vending sites in a small town in Zambia. J. Fd Prot. 60, 391-398.

FAO/GHANA (1997) Survey on the street food situation in Ghana (SFSIG), pp. 41-50.

Farkas, J., Saray, T., Mohacsi-Farkas, C., Horti, K. \& Andrassy, E. (1997) Effects of low-dose gamma radiation on shelf-life and microbiological safety of precut/prepared vegetables. Adv. Fd Sci. (CMTL) 19 (3/4), 111-119.

GLSS (a) (1988/89) Ghana Living Standards Survey. Ghana Statistical Department.

GLSS (a) (1998/99) Ghana Living Standards Survey. Ghana Statistical Department.

Hayford, G. (1979) The microbiological quality of cooked chicken pieces on sale (B Sc Dissertation). University of Ghana.

IAEA (2003) Radiation processing for safe, shelf-stable and ready-to-eat food. IAEA-TECDOC-1337, Vienna.

ICMSF (1989) Microorganisms in foods. 4. Application of hazard analysis critical control point (HACCP) system to ensure microbiological safety and quality. Oxford Blackwell Scientific Publication.

Klipstein, F. A., Engert, R. F. \& Short, H. B. (1977) Relative enterotoxicity of coliform bacteria. J. Infect. Dis. 136, 205-215.

Mosupuye, F. M. \& von Holy, A. (1999) Microbiological quality and safety of ready-to-eat street-vended foods in Johannesburg, South Africa. J. Fd Prot. 62 (11), 1278-1284.

Mac Faddin, J. F. (1980) Biochemical tests for identification of medical bacteria. USA, Williams and Wilkins, Baltimore.

Nkansah, J. O. (1996) Food hygiene and sanitation in selected food service establishments (B Sc Dissertation). University of Ghana.

Swanepoel, F. J. J., Hobbs, C., Becker, P. J. \& Ijsselmuiden, C. (1995) The quality of food sold by traders in Central Johannesburg and factors associated with contamination. J. Compr. Hlth 6, 188190. 